\title{
Initiation of an active margin at the North Iberian continent-ocean transition
}

\author{
J. Gallastegui and J. A. Pulgar \\ Departamento de Geología, Universidad de Oviedo, Oviedo, Spain
}

\section{J. Gallart}

Instituto de Ciencias de la Tierra, Jaume Almera, Consejo Superior de Investigaciones Científicas, Barcelona, Spain

Received 9 November 2001; revised 14 March 2002; accepted 25 March 2002; published 21 August 2002.

[1] The North Iberian or Cantabrian margin, located at the southern flank of the Bay of Biscay, underwent successive tectonic regimes of rifting, passive margin, and compression from Mesozoic to Tertiary times. A complete crustal cross section of the North Iberian Margin, from the abyssal plain to the shoreline, and a reconstruction of its undeformed Upper Cretaceous structure are presented here. It is constrained after the compilation and interpretation of different geophysical data sets recently available in the area. The reflective pattern is provided by deep seismic reflection profile ESCIN-4, complemented by commercial profiles and well information from the North Iberian platform, and the velocity-depth control comes from an onshoreoffshore wide-angle seismic profile, tested also with gravity modeling. The detailed cross section of the Meso-Tertiary basins that fill the platform and abyssal plain shows structures from the three main tectonic events: (1) normal faults and asymmetric basins from the Permian to lower Cretaceous extensional stage; (2) Upper Cretaceous sediments deposited under stable conditions during the passive margin period; and (3) inverted faults, thrusts and folds related to the Tertiary compression. The deep structure of the crust beneath the margin is poorly constrained from ESCIN-4 profile that shows reflectivity in the lower crust only at a small area under the platform. However, the corresponding wide-angle experiment provides a conspicuous image of the Moho that shows a continued deepening toward the continent. On the basis of the geophysical results, we propose a new model for this margin where the lower crust is detached and underthrusted to the south as a result of the partial closure of the Bay of Biscay. An interpreted Mesozoic crustal-scale extensional detachment could be the weakness zone that allowed the lower crust to "slide" southward under the upper crust, resulting in the indentation of the Cantabrian Margin lower crust into

Copyright 2002 by the American Geophysical Union. 0278-7407/02/2001TC901046 the Iberian crust. Plate convergence stopped at an early stage, making this a unique area to study the initial stages of deformation of a passive margin. INDEX TERMS: 8105 Tectonophysics: Continental margins and sedimentary basins; 8015 Structural Geology: Local crustal structure; 3025 Marine Geology and Geophysics: Marine seismics (0935); KEYWORDS: deep seismic reflection, ESCIN-4 profile, crustal structure, North Iberian continental margin, Bay of Biscay

\section{Introduction}

[2] The North Iberian Margin or Cantabrian Margin, trends E-W in the southern border of the Bay of Biscay (Figure 1). It is the conjugate of the Armorican Margin, in the North, and marks the present northern boundary of the Iberian plate. Due to its location at the limit between the European and African plates, it has suffered different tectonic regimes during its evolution since the Lower Palaeozoic, when the North Iberian and Armorican margins where juxtaposed as part of the collisional European Variscan chain [Matte, 1991].

[3] The present-day architecture of the margin and of the Cantabrian Mountains in the south, which are the western prolongation of the Pyrenees, results from the superposition of two almost orthogonal orogenic events: the E-W Variscan orogeny [Pérez-Estaún et al., 1988] and the approximately NW-SE Tertiary Alpine orogeny [Alonso et al., 1996; Pulgar et al., 1996]. Both events were separated by several extensional episodes that started by rifting in the Permian to Late Jurassic and evolved to an oceanic stage in the Bay of Biscay, with seafloor spreading that lasted until Late Cretaceous (Figure 2) [Martínez-García, 1982; Vegas and Banda, 1982; Boillot et al., 1984; Verhoef and Srivastava, 1989]. The main effects of the Alpine orogeny were as follows: the NW-SE Cenozoic oblique convergence between the Iberian and European plates, the partial closure of the Bay of Biscay, the deformation of the margin and the uplift and deformation of the Cantabrian Mountains [Le Pichon et al., 1971; Boillot et al., 1979; Grimaud et al., 1982; Srivastava et al., 1990b; Alonso et al., 1996; Álvarez-Marrón et al., 1997]. The end of convergence, at the end of the Miocene, aborted the collision between the plates, that had already started further west in the Pyrenean region [Boillot and Capdevila, 1977; Williams and Fischer, 1984; Séguret and Daignières, 1986; Etude Continentale et Océanique par 


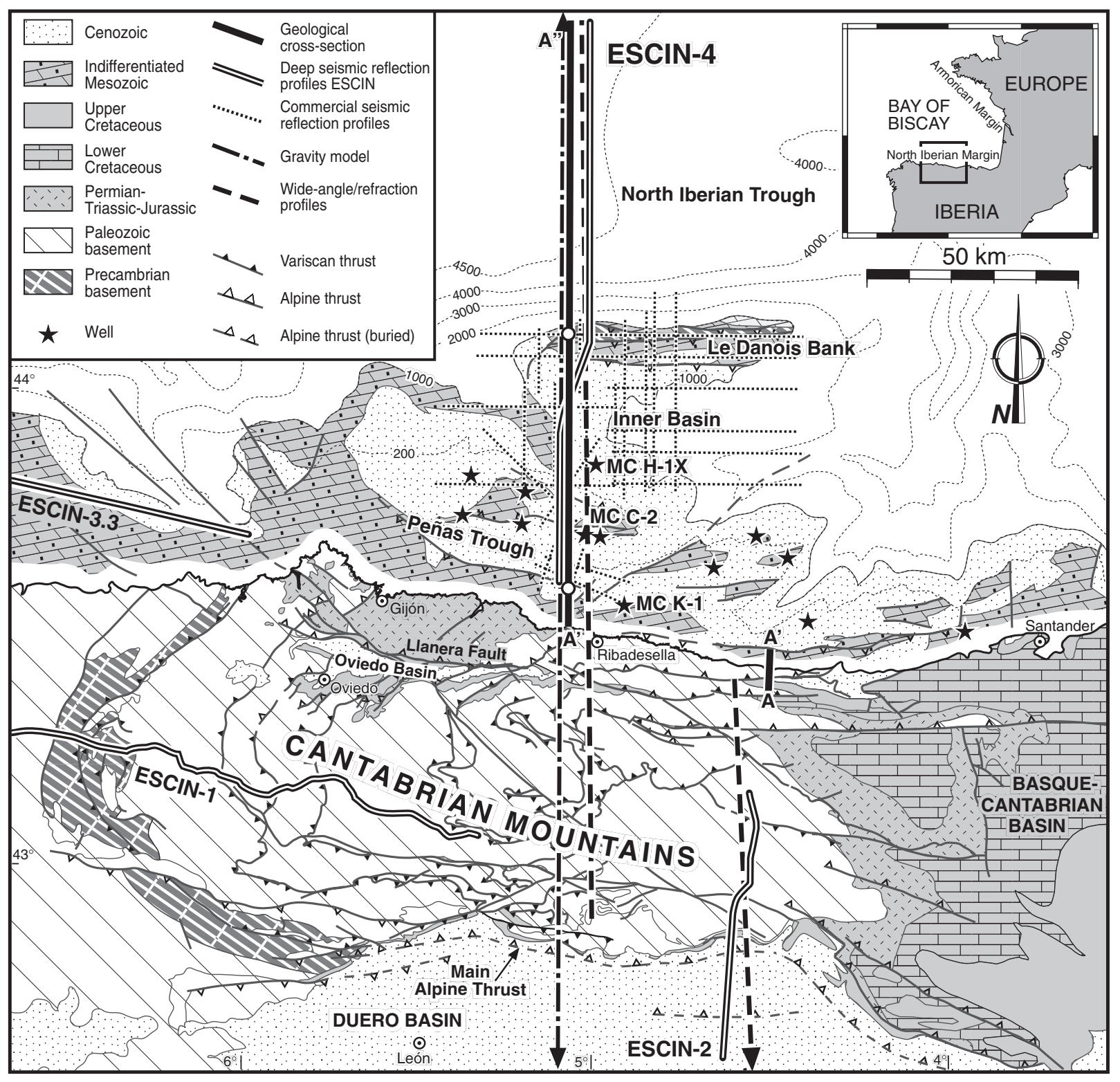

Figure 1. Simplified geological map of NW Iberia and its continental platform with the location of the geological cross section (A-A'-A'; Figure 8) and geophysical data mentioned in the text and shown in Figure 7. Bathymetric contours are in meters.

Reflexion et Refraction Sismique (ECORS) Pyrenees Team, 1988; Roure, 1989; Muñoz, 1992]. This complex tectonic evolution and the fact that plate convergence stopped at an early stage, makes it a unique area to study the superposition of two orthogonal orogenic events and the initial episodes of deformation of a passive margin.

[4] The Variscan structure of the Cantabrian Mountains has been extensively studied [e.g., Julivert, 1971; PérezEstaún et al., 1988; Dallmeyer and Martínez-García, 1990], but its Alpine structure has only been recently investigated [Alonso et al., 1996; Pulgar et al., 1996, 1999]. The geology and evolution of the margin was also the aim of extensive research, particularly in the 70's-80's [e.g., Boillot et al., 1971, 1979; Montadert et al., 1971; Malod and
Boillot, 1980; Malod et al., 1982; Boillot and Malod, 1988]. Crustal seismic information in North Spain was restricted to the Pyrenees in the NE and Galicia in the NW [Gallart et al., 1981; Daignières et al., 1982; Córdoba et al., 1987, 1988]. The ESCIN project (Spanish acronym for Seismic Studies of the North Iberian Crust) was developed in the 90's to fill the $500 \mathrm{~km}$ gap between both areas. This project included the acquisition (Figure 1) of four multichannel deep seismic reflection profiles (two offshore and two onshore) across strike of the Variscan and Alpine structures, respectively [Pérez-Estaún et al., 1994; Álvarez-Marrón et al., 1996, 1997; Pulgar et al., 1996; Gallastegui et al., 1997; Ayarza et al., 1998; Gallastegui, 2000]. ÁlvarezMarrón et al. [1997] showed the tectonic inversion of the 


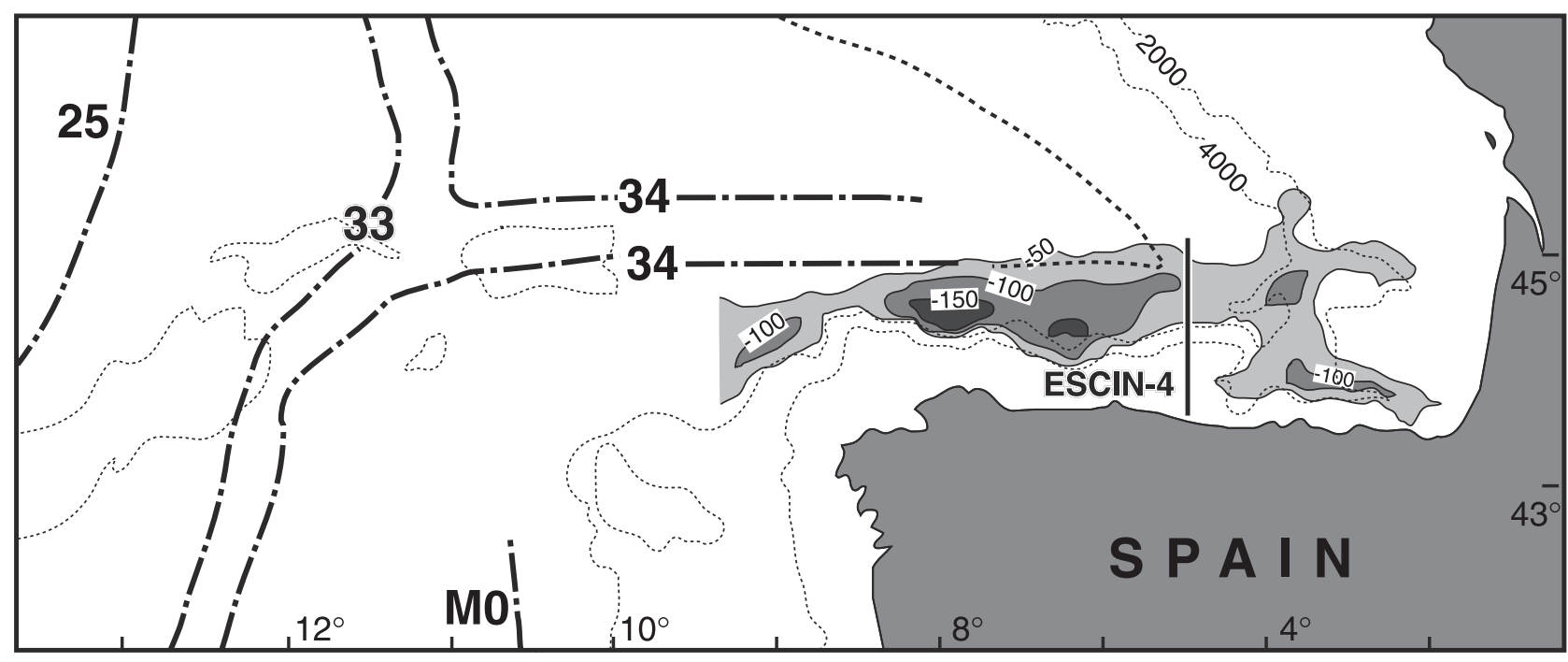

Figure 2. Map of offshore negative gravity anomalies (contours in mGal) in the Iberian Trough [Lalaut et al., 1981] and magnetic lineations in the Northeast Atlantic and Bay of Biscay (M0 - Upper Aptian; 34 - Santonian) [Srivastava et al., 1990a]. Dotted line represents the east boundary of the oceanic crust in the Bay of Biscay according to Derégnaucourt and Boillot [1982]. Bathymetric contours are in meters.

Mesozoic sedimentary basin in the Iberian platform imaged in ESCIN-4 and interpreted an accretionary prism at the foot of the continental slope along the Iberian Margin. A set of wide-angle/refraction profiles from complementary projects was recorded in the northern part of the Iberian Peninsula and continental margin that showed an important Alpine duplication of the crust beneath the Cantabrian Mountains [Pulgar et al., 1996; Fernández-Viejo, 1997; Gallart et al., 1997; Ayarza et al., 1998; Fernández-Viejo et al., 1998, 2000].

[5] This paper focuses on the seismic expression of the architecture of this margin along the N-S transect of ESCIN-4 profile (Figure 1) and on the evolution of the Mesozoic and Alpine structures developed there. A detailed interpretation of ESCIN-4 and other geological and geophysical data available on the North Iberian Margin have been integrated to built up the first complete geological cross section along the transect, and a Cretaceous reconstruction of the margin before its Tertiary deformation. The data include wide-angle and gravity information acquired and interpreted within ESCIN and complementary projects, together with commercial seismic reflection profiles and oil exploration well data from the platform area.

\section{Geological Framework and Tectonic Evolution}

[6] The Paleozoic materials that crop out in the studied area are part of the foreland thrust and fold belt of the Iberian Variscan Orogen and constitute the basement that underwent deformation during the Mesozoic and Tertiary. The overall Variscan structure in NW Spain is east verging, with a geological zonation from the hinterland areas in the west to the foreland and most external ones in the east
(Figure 1). However, the Variscan chain shows a tight arcuate shape and structures in the studied area verge to the south (near Ribadesella in Figure 1), in the core of the Asturian arc [Julivert, 1971; Pérez-Estaún et al., 1988, 1994]. The Paleozoic rocks are mainly sedimentary and consist of a kilometric succession of sandstones, shales, and limestones deformed under shallow conditions.

[7] The present geometry of the Mesozoic and Tertiary rocks that crop out in the Cantabrian Mountains near the coastline is related to Alpine structures such as the Llanera fault, and the reworking of Variscan thrusts. The Llanera fault is an extensional Mesozoic structure that was later inverted during the Tertiary and is the northern boundary of the Oviedo Tertiary basin (Figure 1) [Alonso et al., 1996; Pulgar et al., 1999]. A PermoMesozoic succession is preserved in its northern downthrow block, while the lower Cretaceous lies directly on top of the basement, in the southern block, and is covered by Tertiary syntectonic deposits (Oviedo Basin).

[8] In the continental shelf the Mesozoic is exposed in a band parallel to the coastline and northward is mostly covered by Tertiary deposits (Eocene-Neogene) [Boillot et al., 1979]. Oil exploration wells show significant lateral thickness variations along the platform. A well located close to the coastline (MCK-1 in Figure 1) reached the basement at $3103 \mathrm{~m}$ depth, but more than $5000 \mathrm{~m}$ of Meso-Tertiary deposits were drilled northward in a well (MCH-1X in Figure 1) that only reached the lower Cretaceous [Lanaja, 1987].

[9] In the Upper Cretaceous the area from the Duero Basin to the present-day shoreline was part of a shallow platform, whereas the present platform constituted the continental slope of the stable margin, as shown by the Upper Cretaceous deep water turbiditic deposits sampled in the platform [Boillot et al., 1979; Boillot and Malod, 1988]. 
[10] The basin was deformed and inverted during the Tertiary compressional stage and north vergent thrusts developed [Boillot et al., 1979; Álvarez-Marrón et al., 1997]. Dives of submersible Cyana and dredges, showed that Variscan basement rocks outcrop in Le Danois Bank and in the upper continental slope, in the hanging-wall of north vergent Tertiary thrusts [Boillot et al, 1979; Malod and Boillot, 1980; Malod et al., 1982]. Other evidences of Tertiary deformation are also present at the foot of the continental slope, along the North Iberian Trough (Figure 1). This trough is filled by Cenozoic sediments that thicken toward the continental slope, and are partly deformed in what was interpreted as an accretionary prism related to the southward subduction of the Bay of Biscay oceanic crust [Boillot et al., 1971, 1979; Montadert et al., 1971; Le Pichon et al., 1971; Boillot and Malod, 1988; ÁlvarezMarrón et al., 1997]. Other evidences proposed for the subduction are the asymmetry of the magnetic anomalies in the Bay of Biscay [Srivastava et al., 1990a], a belt of negative gravity anomalies and the presence of an interpreted relict marginal trench along the foot of the continental slope (Figure 2) [Le Pichon et al., 1971; Sibuet and Le Pichon, 1971; Lalaut et al., 1981].

\section{Geophysical Constraints on the Architecture of the Cantabrian Margin}

\subsection{Vertical Seismic Reflection Profiles}

[11] Vertical seismic reflection profiles, particularly ESCIN-4, are the main source of information used to construct the N-S transect in the North Iberian Margin. To build up the geological cross section on the Cantabrian platform we will also consider the interpretation of 25 commercial seismic reflection profiles (Figure 1) that display a more detailed seismic image of the sedimentary basin. Data from several oil exploration wells in the platform (MC C-2, MC K-1, MC H-1X) have been used to distinguish and date the reflectors from the sedimentary basin [Lanaja, 1987].

[12] Profile ESCIN-4 was acquired in 1993 to investigate the N-S crustal structure of the North Iberian Margin in the transition from the continental to the oceanic domains (Figure 3). The profile runs from the coastline in the south, to the center of the Bay of Biscay in the north. Significant changes in bathymetry are encountered along the profile (from 0 to $200 \mathrm{~m}$ in the continental shelf to $900-1000 \mathrm{~m}$ in the Inner Basin and Bank Le Danois and $4000-5000 \mathrm{~m}$ at the abyssal plain, with a steep continental slope $\sim 17^{\circ}$ ) (Figure 1). Detailed information on data acquisition and processing parameters for this profile are given by Álvarez-Marrón et al. [1996]. In this paper we will specially focus on the crustal structure of the margin and on the structure of the Meso-Tertiary deposits that fill the Iberian platform and the abyssal plain. Most distinctive features identified are reported hereafter. Main reflective levels have been subsequently converted to depth using the velocity model presented in section 3.2 (see Figure 7c).
[13] The Iberian platform is highly reflective in the upper $4 \mathrm{~s}$ and reflectors are especially coherent in the upper $2 \mathrm{~s}$ (Figures 3 and 4). A band of south dipping reflectors (A in Figures 3 and 4) under Le Danois Bank and the Inner Basin has been interpreted as the base of the Meso-Tertiary basin that filled the margin. Its base is more diffuse under the Peñas Trough, where less coherent energetic dipping reflectors at $4 \mathrm{~s}$ (A) can be traced. The basement is almost transparent seismically and deep reflectivity is restricted to the area under the Peñas Trough, where a group of south dipping reflections (B) are imaged between 9 and $11 \mathrm{~s}$. At the southern end of the profile, shallow reflectors show a synformal shape in the Peñas Trough. A band of coherent reflectors (C), identified as the upper Cretaceous, is onlapped to the north and south in both flanks of the Peñas Trough by the upper package of Tertiary reflectors (D), which can be divided in two sequences by an intermediate unconformity (interpreted in Figure 6a). Band C is folded and disrupted by several north dipping inverted faults on both flanks of the trough. Reflectivity decreases below the upper Cretaceous in both commercial and deep seismic reflection profiles, holding up the interpretation of the lower part of the sedimentary basin and the Paleozoic basement. Upper reflections draw an open antiform (E) in the transition from the continental shelf to the Inner Basin. Coherent reflections above band A dip gently to the south and show a wedge shape in the Inner Basin (CDP 2400-4400). Three depositional sequences have been identified in the upper two seconds, corresponding to Tertiary sequences deposited unconformably on the Cretaceous levels (Figure 6). The two lower sequences are syntectonic. They are deformed by thrusts rooted in the Mesozoic levels and can be correlated with reflectors D identified in the Peñas Trough. The uppermost sequence, found in the Inner Basin, is undeformed and constitutes the posttectonic level.

[14] Reflectivity decreases beneath the continental slope, but several north dipping shallow events can be traced dipping less than the sea bottom (F) (Figures 3 and 4). These events bend landward, changing their dip to the south under Le Danois Bank. These surfaces are curved as an effect of the abrupt increase in water depth from the platform to the abyssal plain (Figure $4 \mathrm{~b}$ ) and they become flat south dipping events after depth conversion (Figure 4c).

[15] The abyssal plain area is highly reflective down to the arrival of the first multiple, at $12 \mathrm{~s}$, that masks all primary signals (Figures 3 and 5). Reflectors are very coherent and energetic, except for those under $7 \mathrm{~s}$ at the foot of the continental slope between CDP's 6000 and 9600, which are folded and disrupted $(\mathrm{J})$. Three different conformable sequences of reflectors are recognized filling the abyssal plain basin and reaching $10 \mathrm{~s}$ depth (Figures 3 and 5). The uppermost one $(\mathrm{G})$ is composed of horizontal and parallel reflectors between 6 and $7 \mathrm{~s}$. Most of them are flat and continuous for more than $70 \mathrm{~km}$ to the $\mathrm{N}$ of the continental slope. The intermediate sequence $(\mathrm{H}$, between 7 and $9 \mathrm{~s}$ in the $\mathrm{S}$ of the profile) is fan-shaped, thins northward and is mostly made of south dipping reflectors that die out in the area where these reflectors are disrupted (J). Several uncon- 

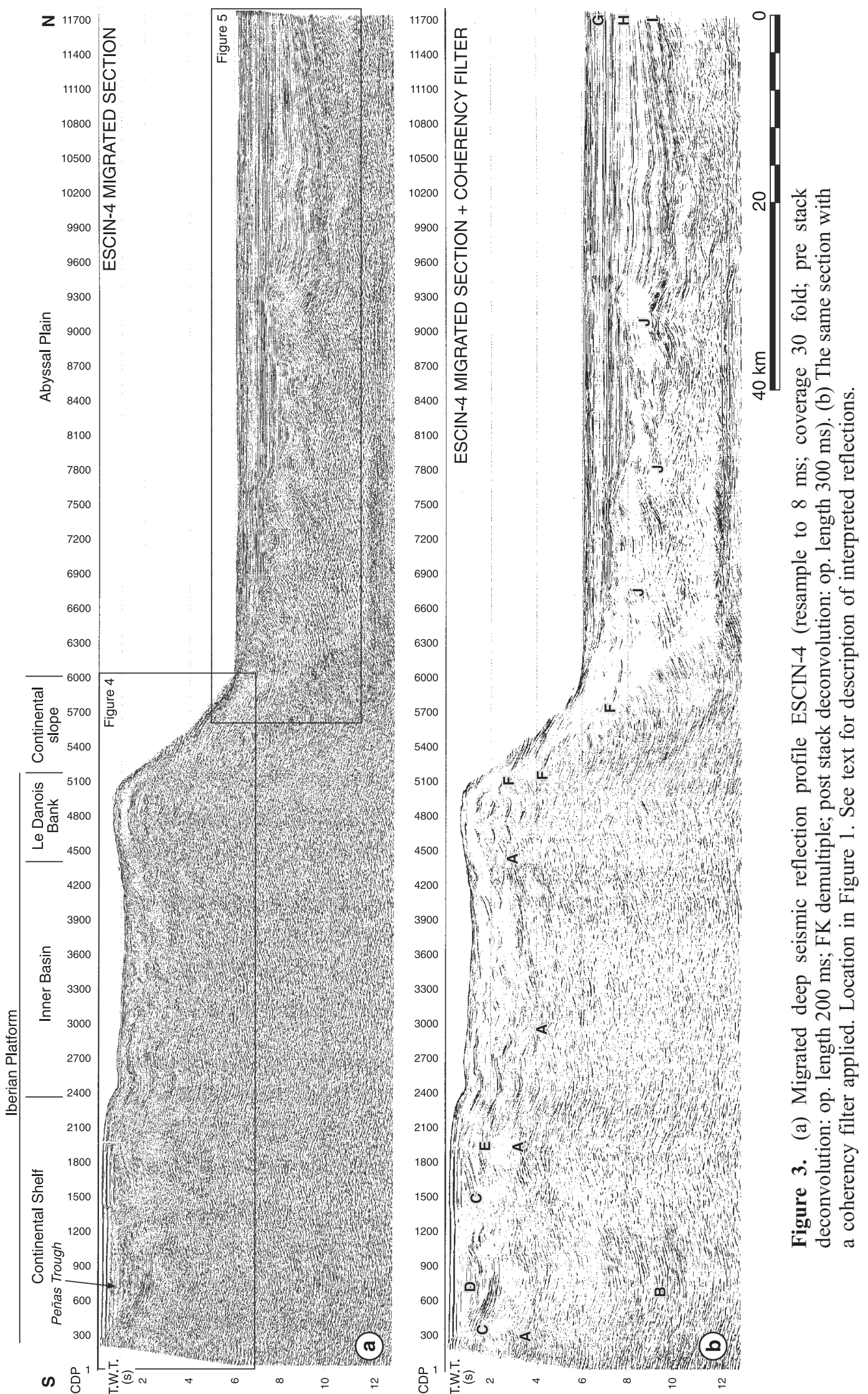


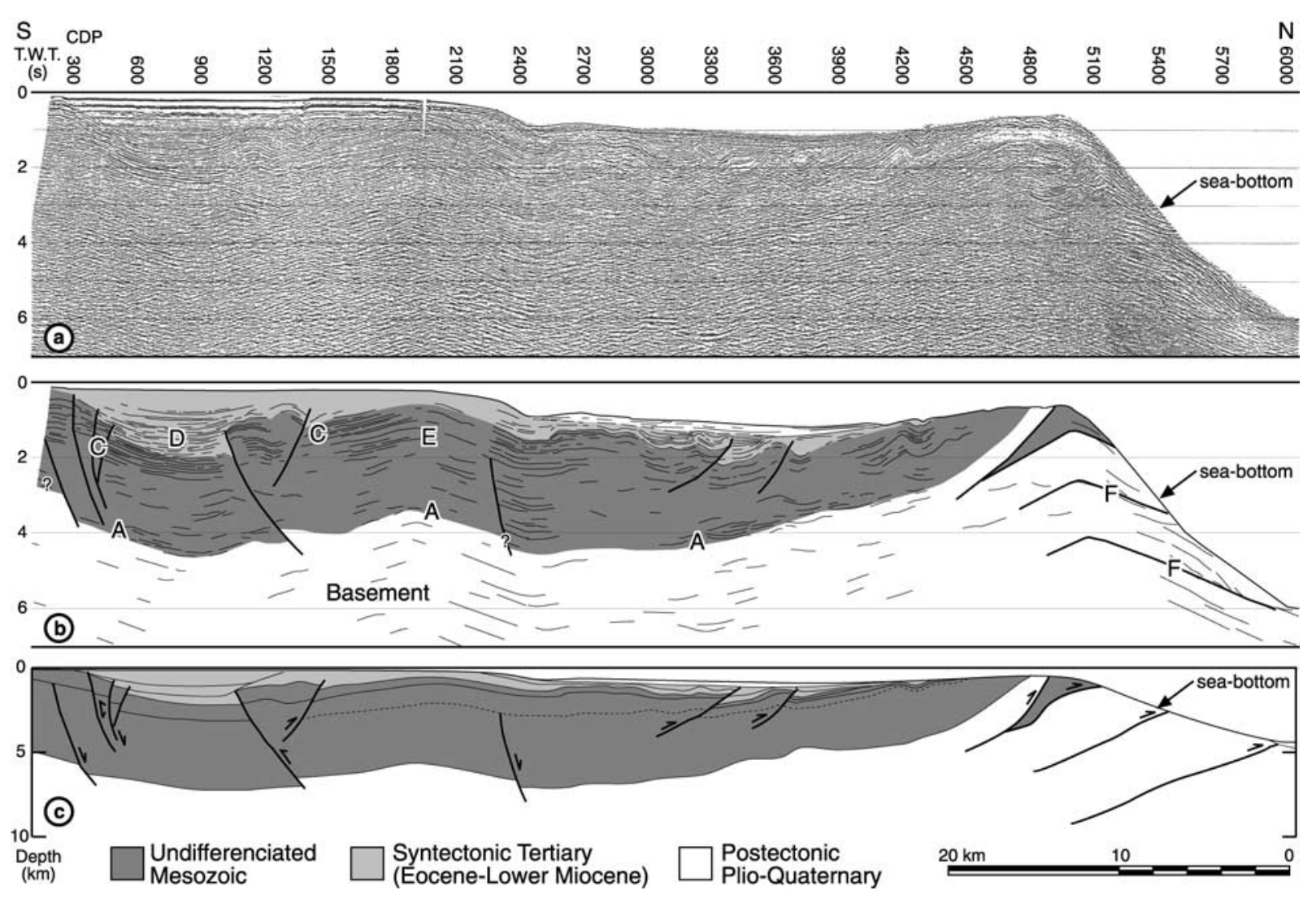

Figure 4. (a) Magnification of the continental platform and continental slope area in migrated deep seismic reflection profile ESCIN-4. (b) Interpretation of the platform and continental slope on profile ESCIN-4 (Figure 3). Gray colors indicate the Meso-Tertiary basin deformed in the Tertiary. (c) Depth converted section.

formities can be traced inside this sequence. The upper sequence $(\mathrm{G})$ and the top of the intermediate $(\mathrm{H})$, unconformably overlap the deformed package of reflectors $(\mathrm{J})$ in the south. The lowest sequence of parallel reflectors is less than $1 \mathrm{~s}$ thick and thins toward the south (I, between 9 and $10 \mathrm{~s}$, north of CDP 9300). The basement below that lowest sequence is energetic, but reflectors lack coherency.

\subsection{Wide-Angle Seismic Data}

[16] Seven autonomous three-component land stations recorded the marine shots from ESCIN-4 reflection profile, providing wide-angle sampling of the margin coincident with ESCIN-4, but extended $70 \mathrm{~km}$ onshore. This data set was analyzed using two different methodologies: classical velocity-depth forward modeling (Figure 7a) [Pulgar et al., 1996; Fernández-Viejo, 1997; Fernández-Viejo et al., 1998], and multichannel processing of Moho reflections [Gallart et al., 1997]. The latter provided a large-aperture stacked section that could be superposed on the conventional ESCIN-4 section to enhance the signature of the crust-mantle boundary beneath the continental platform. The Moho thus appears as a continuous reflector deepening landward (Figure 7b). The velocity-depth model (Figure 7a) shows $P$ wave velocities in the range of $5.6-6.35 \mathrm{~km} / \mathrm{s}$ for the upper and middle crust. The lower crust and the Moho are well defined throughout the profile, from the shoreline to the abyssal plain. Velocities in the lower crust increase northward from $6.6 \mathrm{~km} / \mathrm{s}$ under the shoreline to $7.3 \mathrm{~km} / \mathrm{s}$ in the abyssal plain suggesting a very thinned continental or oceanic-type crust. Moho deepens southward from $17 \mathrm{~km}$ in the abyssal plain, to $22 \mathrm{~km}$ under the continental slope and $30 \mathrm{~km}$ beneath the shoreline. A second deeper "Iberian Moho", which has also been imaged inland dipping to the north in deep seismic reflection profile ESCIN-2, is modeled beneath the Cantabrian Mountains reaching almost $60 \mathrm{~km}$ depth. This deep seismic image has been interpreted as an imbrication of two crusts, the Iberian crust in the south and the Cantabrian Margin crust in the north, due to the northward underthrusting of the former beneath the latter [Pulgar et al., 1996; Fernández-Viejo, 1997; Gallart et al., 1997; Fernández-Viejo et al., 1998]. This crustal root was also found in other E-W seismic experiments under the Cantabrian Mountains, like a refraction profile [FernándezViejo et al., 2000] and the deep seismic reflection profile ESCIN-1 [Gallastegui, 2000].

\subsection{A Seismic Cross Section}

[17] A time-velocity model for profile ESCIN-4 has been constructed (Figure 7c), based on the interpretation of the different crustal levels and reflectors. It can subsequently be 


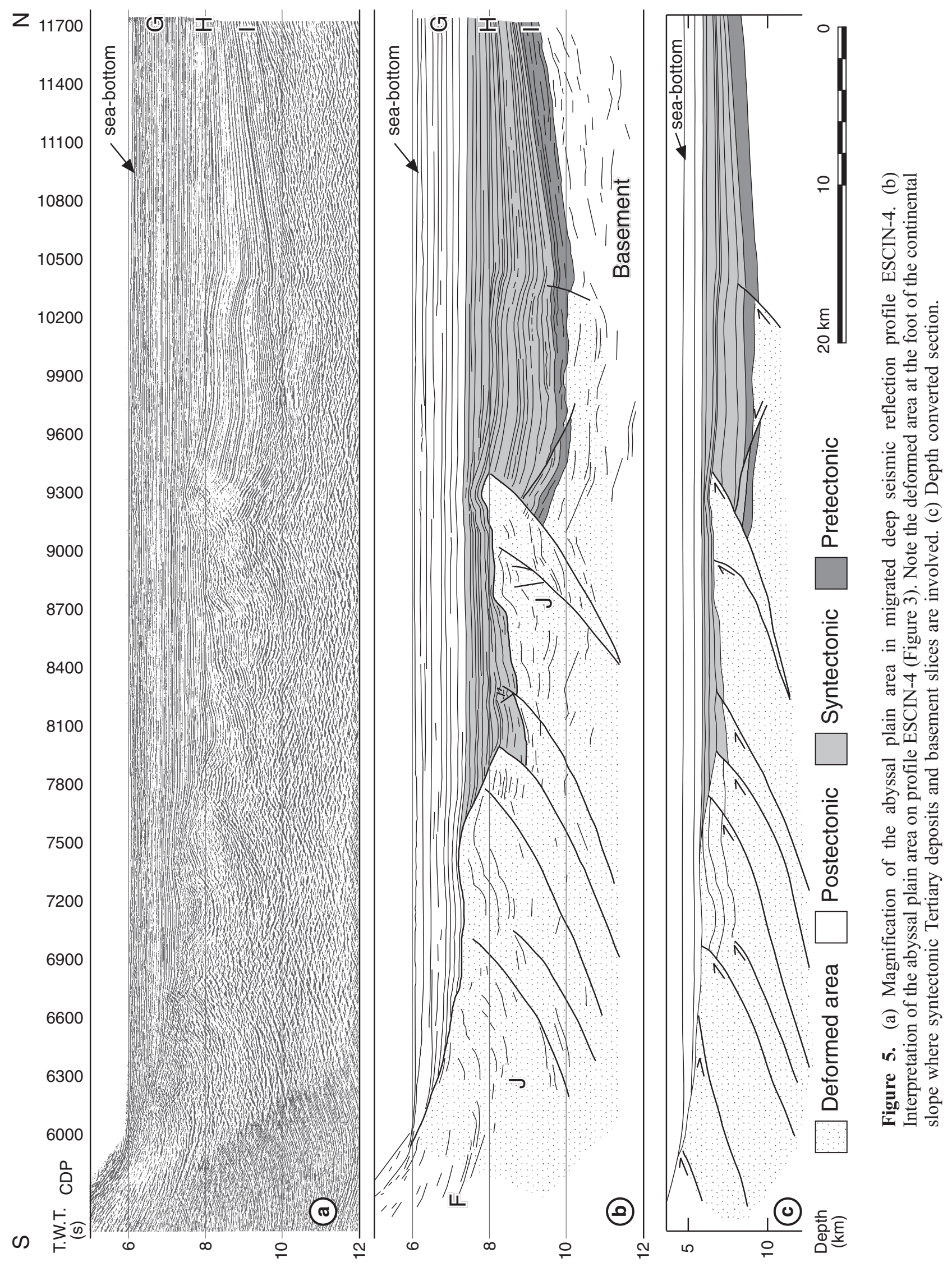


converted to depth, and include onshore data, to construct a geological cross section from the coastline to the abyssal plain (Figure 7d). The velocity information integrated in this model comes from several sources: velocities for the sediments that fill the abyssal plain are obtained from Montadert et al. [1971], Sibuet et al. [1971], and Álvarez-Marrón et al. [1997]; values in the platform are calculated from stack and well information; the structure of the sedimentary basins and upper crust is directly derived from seismic reflection data (ESCIN-4 and commercial profiles), and finally, wide-angle velocity models provide the information for lower crustal and mantle levels [Pulgar et al., 1996; Fernández-Viejo, 1997; Gallart et al., 1997].

\subsection{Gravity Modeling}

[18] To provide further constraints on the crustal interpretation from seismic data, 2-D gravity modeling has been carried out on two N-S profiles, from the Duero Basin to the Bay of Biscay [Gallastegui, 2000]. In this paper we present the offshore portion of the western profile coincident with ESCIN-4 (see Figure 1), but the calculated gravity curve includes the gravity effect of the crustal structure beneath the Cantabrian Mountains in the S (Figure 7e). A gravity anomaly map was compiled from offshore Free-Air data [Sandwell and Smith, 1997] and onshore Bouguer data collected from the BGI (Bureau Gravimétrique International) and complemented with new measurements collected inland for this research. Gravity anomalies in the margin trend $\mathrm{E}-\mathrm{W}$, parallel to the direction of the main bathymetric features (Figure 2). A steep gradient separates a gravity low $(-120 \mathrm{mGal})$, at the foot of the continental slope along the margin, from a gravity high $(120 \mathrm{mGal})$ at Le Danois Bank and the rest of the platform [Gallastegui, 2000]. Densities for the different crustal levels have been calculated and compiled in the model of Figure 7c after the $P$ wave velocities [Ludwig et al., 1970] obtained from several sources: (1) the wide-angle model mentioned before, (2) well data in the platform, and (3) stack and migration velocities in the abyssal plain sediments [Montadert et al., 1971; Sibuet et al., 1971; Álvarez-Marrón et al., 1997].

[19] The observed gravity curve along the profile (Figure 7f) is appropriately fitted by the one calculated from the density model of Figure 7e, which is well in agreement with geological and seismic models. The shape of the most prominent anomaly, characterized by a high-low pair (Figure 7f), is typical of most continental margins due to the edge effect related to the increase of water depth and the mantle shallowing toward the oceanic domain. In this case, the anomaly high is increased by the presence of basement rocks at Le Danois Bank and along the continental slope, and the anomaly low is increased by the thick pile of sediments at the foot of the continental slope. Densities range between 1.9 and $2.63 \mathrm{~g} / \mathrm{cm}^{3}$ for the sedimentary levels and between 2.7 and $2.75 \mathrm{~g} / \mathrm{cm}^{3}$ for the upper and middle crust. The lower crust has been modeled as a continuous level with density increasing northward $\left(2.92-2.95 \mathrm{~g} / \mathrm{cm}^{3}\right)$, in agreement with the seismic velocity-depth model (Figure 7a). This density model is similar to those proposed further to the west along the margin by Fernández-Viejo et al. [1998].

\section{Geological Interpretation}

[20] The overall structure imaged along the N-S transect is that of a Mesozoic passive continental margin that resulted from an extensional event and later underwent a limited compression in the Tertiary that reworked the crustal geometry. The restricted Alpine deformation suffered by the margin allowed us to reconstruct its Upper Cretaceous passive margin geometry and the evolution of the structure due to the Tertiary compression (Figure 8).

[21] Extension spanned from Permian to Lower Cretaceous and resulted in the development of N120E listric normal faults with the downthrown block to the north, similar to examples mapped inland. Due to the lack of resolution of the seismic profiles under the upper Cretaceous level (post-rift), there is no seismic expression of these faults in the margin. However, the presence of analogous faults inland, truncation of reflectors and differences in sediment thickness in short distances, found in exploration wells, allowed us to interpret several north dipping normal faults that divide the basin into sub-basins. These sub-basins are asymmetric, increasing their thickness to the south and reaching maximum depths of $6 \mathrm{~km}$ (see Figure 6). Upper Cretaceous levels are not affected by the normal motions of the faults, giving thus a maximum age for their displacement. In the reconstruction of the margin (Figure 8), a set of normal faults in the paleocontinental slope have also been interpreted, in a model analogous to the one proposed for the undeformed northern conjugate Armorican Margin [Le Pichon and Barbier, 1987]. We have interpreted that these faults converge in a basal extensional detachment or shear zone located on top of the lower crust.

[22] The effects of the compression due to the closure of the Bay of Biscay in the Tertiary are present all over the margin. The shortening of the margin is evidenced by (1) northward emplacement of thrusts in the Inner Basin, that are rooted in the Mesozoic succession and associated with growth ramp folds and syntectonic Tertiary deposits; and (2) development of open folds such as the one between the Peñas Trough and the Inner Basin (under CDP 2000 in Figure 4b). Coeval deformation is also found inland (for example in the extensional Llanera fault) and in the normal faults that bound the Peñas Trough to the north and south, that were reactivated as reverse fault. Inversion in the Peñas Trough was also accommodated by the northward rotation of the upper section of the fault planes in the north and development of inversion anticlines between inverted faults in the south, as the one below well MC-C2. The detailed interpretation of the Tertiary reflectors evidenced two unconformable syntectonic sequences ( 1 and 2 in Figure 6), and a posttectonic sequence (3), that date the deformation in the margin. The lowermost syntectonic sequence " 1 " is Upper Eocene. It onlaps the southern border of the Peñas Trough, showing that the area to the south of the Peñas Trough was undergoing deformation and uplift, whereas it lays conformably in the rest of the platform that was almost stable. This is 

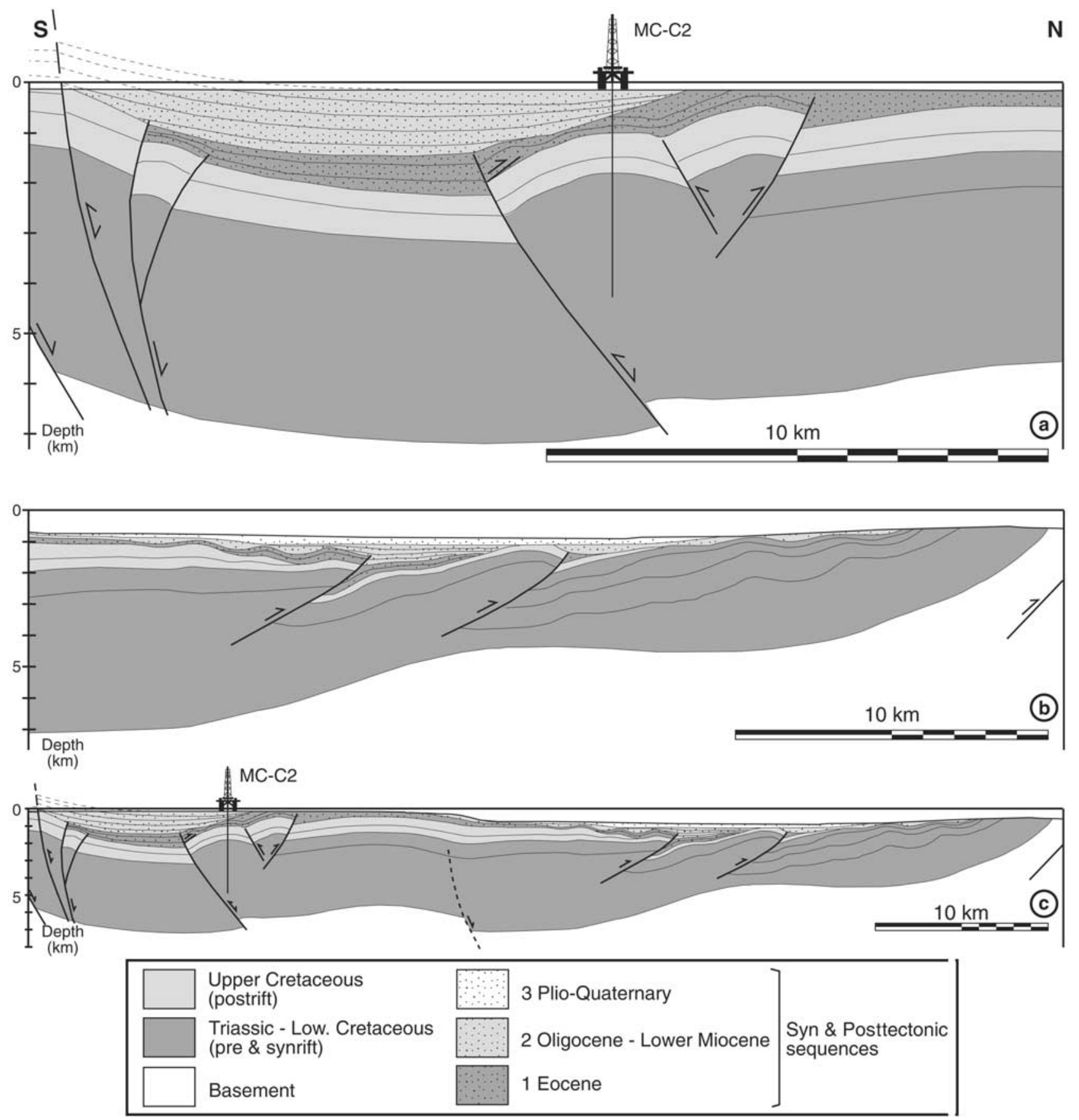

Figure 6. ( $\mathrm{a}$ and $\mathrm{b}$ ) Depth converted interpretation of two commercial seismic reflection profiles close to deep seismic reflection profile ESCIN-4 showing the tectonic inversion that affected the platform in the Tertiary. Note the three sedimentary sequences defined in the Tertiary-Quaternary: sequences 1 and 2 are syntectonic, and sequence 3 is posttectonic. (c) Detailed geological cross section of the platform derived from the interpretation of commercial seismic reflection profiles. Both ends of the cross section are located as white circles along profile $\mathrm{A}^{\prime}-\mathrm{A}^{\prime \prime}$ in Figure 1.

in agreement with the Upper Eocene inversion of the Llanera fault inland and the start of uplift in the Cantabrian Mountains. Deformation extended to the rest of the platform during the Oligocene-Lower Miocene when syntectonic sequence " 2 " deposited and there was a general uplift and inversion of structures in the Cantabrian Mountains. This sequence onlaps on both sides of the Peñas Trough and is coeval with its shortening. In the Inner Basin, it is syntectonic with thrusting and thrust-related fold growth. The uppermost sequence " 3 " is posttectonic and onlaps on the northern and southern margins of the Inner Basin (Le Danois Bank and continental platform, respectively). 
[23] Most conspicuous deformation in the margin is concentrated at the continental slope and the deformed area at its foot. Malod and Boillot [1980] identified thrusts at the top of the continental slope that superpose basement on Mesozoic and we have interpreted the structure of the whole continental slope as an imbrication of thrusts, mostly emplaced in basement rocks. However, it is impossible to identify the type of superposition in the lower part of the continental slope and the amount of shortening, due to the poor reflectivity and lack of displacement markers. The imbricate structure produced the shortening and steepening of the continental slope and the uplift of the present platform that was previously part of the Cretaceous continental slope (Figure 8). There is a $4 \mathrm{~km}$ thick pile of sediments at the foot of the continental slope. The deformed area at the foot of the continental slope had previously been interpreted as an accretionary prism related to the southward subduction of the Bay of Biscay oceanic crust under the Iberian Margin [Le Pichon et al., 1971; Boillot et al., 1979; Srivastava et al., 1990b; Álvarez-Marrón et al., 1997]. In our model (Figure 8), we consider that this set of north verging thrusts is the continuation of the imbricate structure developed at the continental slope. The deformed area has been modeled with a density (Figure 7e) and a velocity (Figure 7c) intermediate between those of the continental slope basement rocks and the Tertiary deposits that fill the abyssal plain since the thrusts involve syntectonic Tertiary rocks and basement slices. The thrusts converge in depth at the Mesozoic extensional detachment located on top of the lower crust, which would thus constitute a crustal scale weakened surface that reworked as a Tertiary compressional feature. This surface favored the southward underthrusting of the Cantabrian Margin crust that indented in the Iberian crust, duplicating the crust and building up a crustal root under the Cantabrian Mountains (see Figure 7a) [Pulgar et al., 1996; Fernández-Viejo, 1997; Gallart et al., 1997; Fernández-Viejo et al., 1998, 2000]. The geometry of the syntectonic reflectors in the abyssal plain shows that thrusts follow a forward sequence of emplacement affecting younger reflectors toward the north. Alvarez-Marrón et al. [1997] dated the syntectonic deposits of the abyssal plain, in ESCIN-4 and a profile further to the west, as Eocene to Lower Miocene, giving the time span of compression associated to the accretionary prism. This age is in concordance with the age of deformation and uplift in the platform and Cantabrian Mountains. There is no clear evidence of tectonic activity after the Miocene in this section, although recent uplift in the shelf and minor present day seismicity associated with NW-SE compression [Herraiz, 2000] suggest that some deformation persists.

\section{Discussion and Conclusions}

[24] The North Iberian Margin underwent a short period of compression during the Tertiary, as a result of the partial closure of the Bay of Biscay, after a rift and passive margin stage that spanned the Permian to Upper Cretaceous. This makes this area a suitable place to study the initial episodes of deformation in a margin prior to the continental collision stage, which took place farther east in the Pyrenees.
[25] A sedimentary basin, up to $6 \mathrm{~km}$ thick, developed from Permian to lower Cretaceous times. The basin was asymmetric, thinning toward the north, and its geometry was controlled by extensional $\mathrm{N} 120^{\circ} \mathrm{E}$ faults, that divided it in a number of smaller connected basins (Figure $8 \mathrm{~b}$ ). These faults have been mapped inland (Llanera fault) and imaged offshore in seismic reflection profiles. We assume that these faults converge at depth in an extensional detachment developed on top of the lower crust, that would play an important role in the later development of the margin. During the Upper Cretaceous oceanic stage in the Bay of Biscay, most of the present margin was part of the continental slope (Figure $8 \mathrm{~b}$ ) and only the area closer to the present-day platform constituted part of the Cretaceous platform, which extended to the Duero Basin in the south and covered the present Cantabrian Mountains area.

[26] The subsequent Tertiary compressional stage shortened the margin and modified its upper and lower crustal structure. The basin suffered tectonic inversion and its deformation was mainly controlled by previous Mesozoic and Variscan structures (Figures 6c and 8a). Normal Mesozoic faults and Variscan thrusts reactivated as reverse faults and developed related folds. The emplacement of north vergent Tertiary thrusts was restricted to the northernmost part of the basin, in the transition to Le Danois Bank. These thrusts developed growth ramp folds and small basins with syntectonic Tertiary deposits. Three different Tertiary sequences have been interpreted in the margin, that allowed establishing the timing of the deformation (Figure 6). The two lower sequences are syntectonic and the upper one is posttectonic. The lowermost sequence is Upper Eocene and evidences that deformation in the margin started in the area to the south of the Peñas Trough, coeval with the onset of uplift and deformation in the Cantabrian Mountains. The rest of the platform remained almost stable until the Oligocene, when deformation expanded northward to the rest of the platform. The second sequence (Oligocene-Lower Miocene) deposited during the main deformation period in the platform, coinciding with the uplift and deformation of the Cantabrian Mountains. There are no evidences of further deformation in the posttectonic Plio-Quaternary sequence deposited in the Inner Basin. However, recent uplift in the coastline and present low-grade seismicity in the area evidence the continuation of minor tectonic activity.

[27] Most of the deformation and shortening at the upper crustal levels concentrated in the imbricate of thrusts that developed along the continental slope and in the deformed area at its foot, where Tertiary rocks and the basement are affected (Figures 4 and 5). This structure was active during the Eocene-Miocene and is responsible for the shortening and uplift of the former Cretaceous continental slope that constitutes the present shelf and shortened continental slope (Figure 8). The calculated shortening of the margin from line-length balancing of the base of the upper Cretaceous and Moho is about $88 \mathrm{~km}$. However, this value has to be taken as a minimum estimate, calculated for this model, due to the lack of control on the precise shortening at the continental slope. The overall shortening estimated for the complete section from the Duero Basin to the Bay of Biscay is $96 \mathrm{~km}$ 

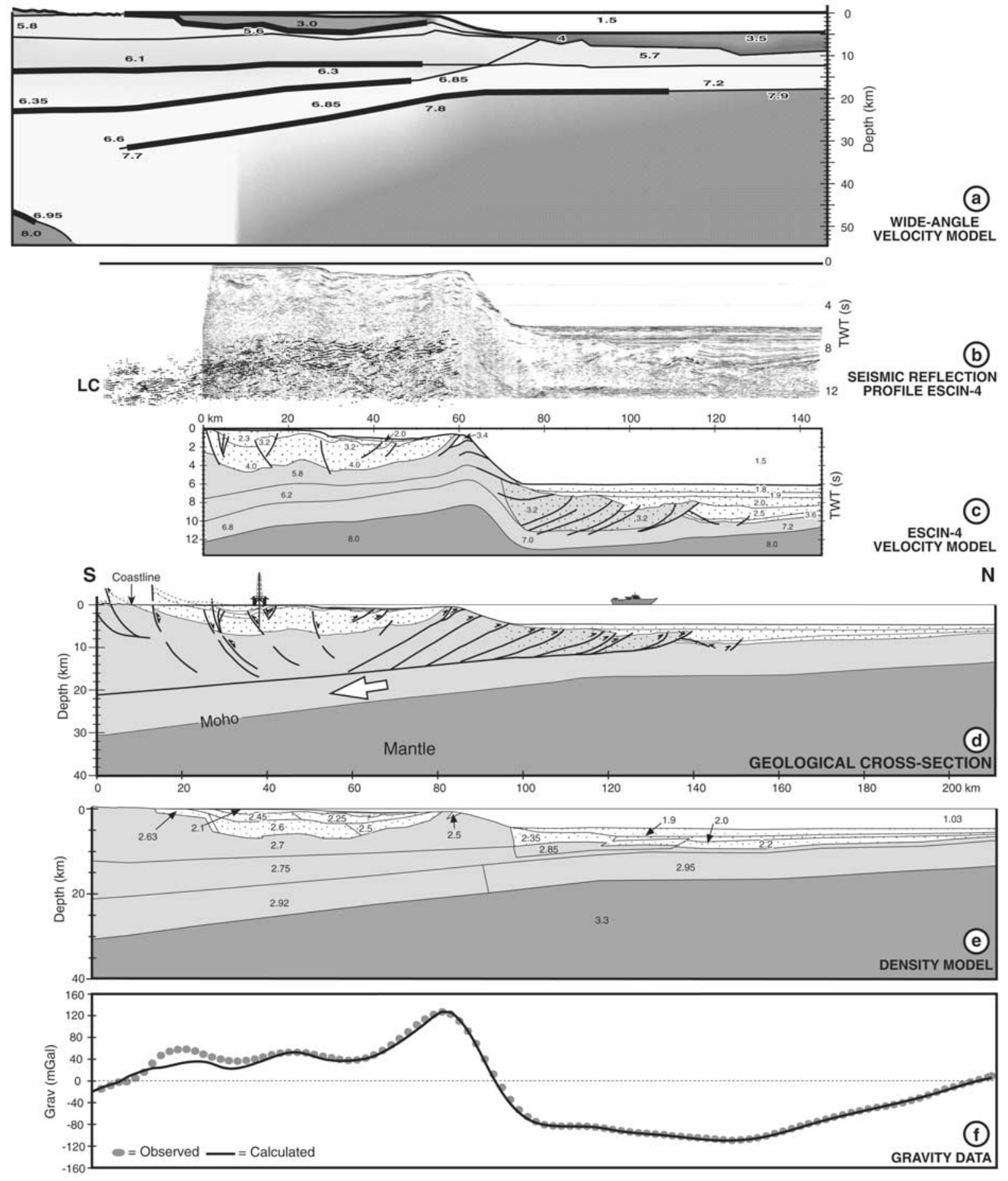

Figure 7. (a) Velocity model derived from wide-angle data. Thick lines represent the segments directly sampled by reflected or refracted seismic phases. [Fernández-Viejo et al., 1998]. (b) Deep seismic reflection profile ESCIN-4. The stacked section (LC) that resulted from multichannel processing of the large-aperture Moho-reflection recorded inland from ESCIN-4 marine shots [Gallart et al., 1997] has been superposed. (c) Velocity model of ESCIN-4 used to convert to depth the main reflective levels interpreted. (d) Geological cross section of the continental margin that synthesizes all information available in the area. (e) Density model of the studied area, based on the velocity distribution, which explains the gravity data. (f) Fitting between observed and calculated gravity anomalies. 

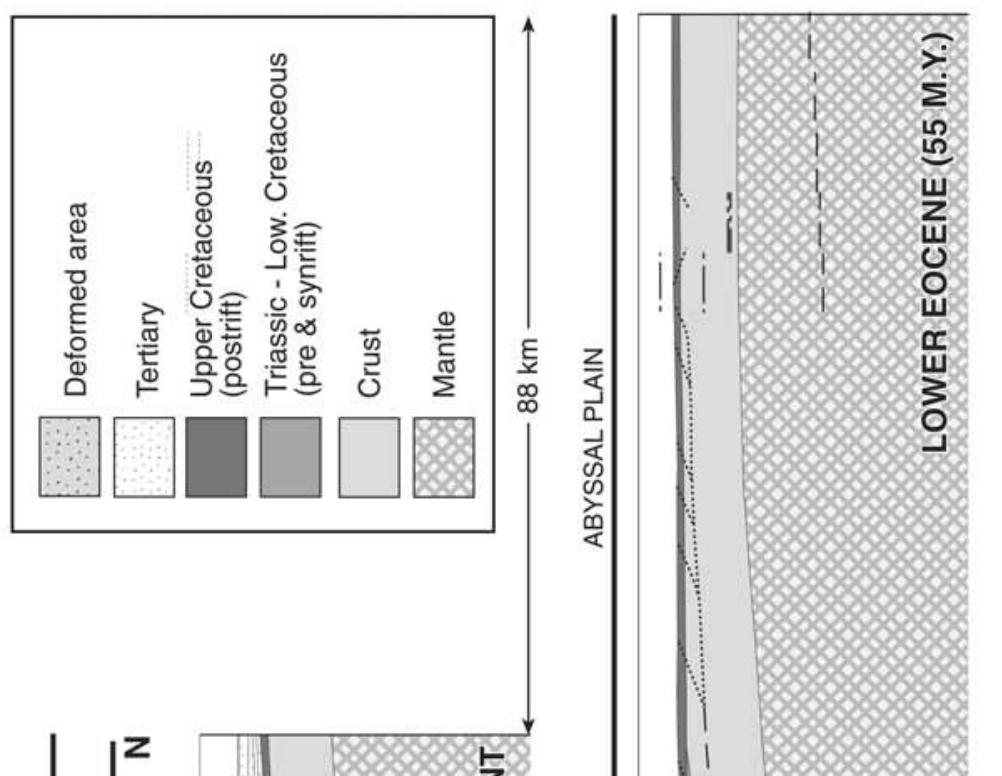

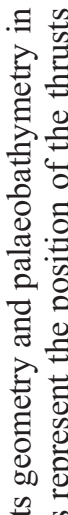
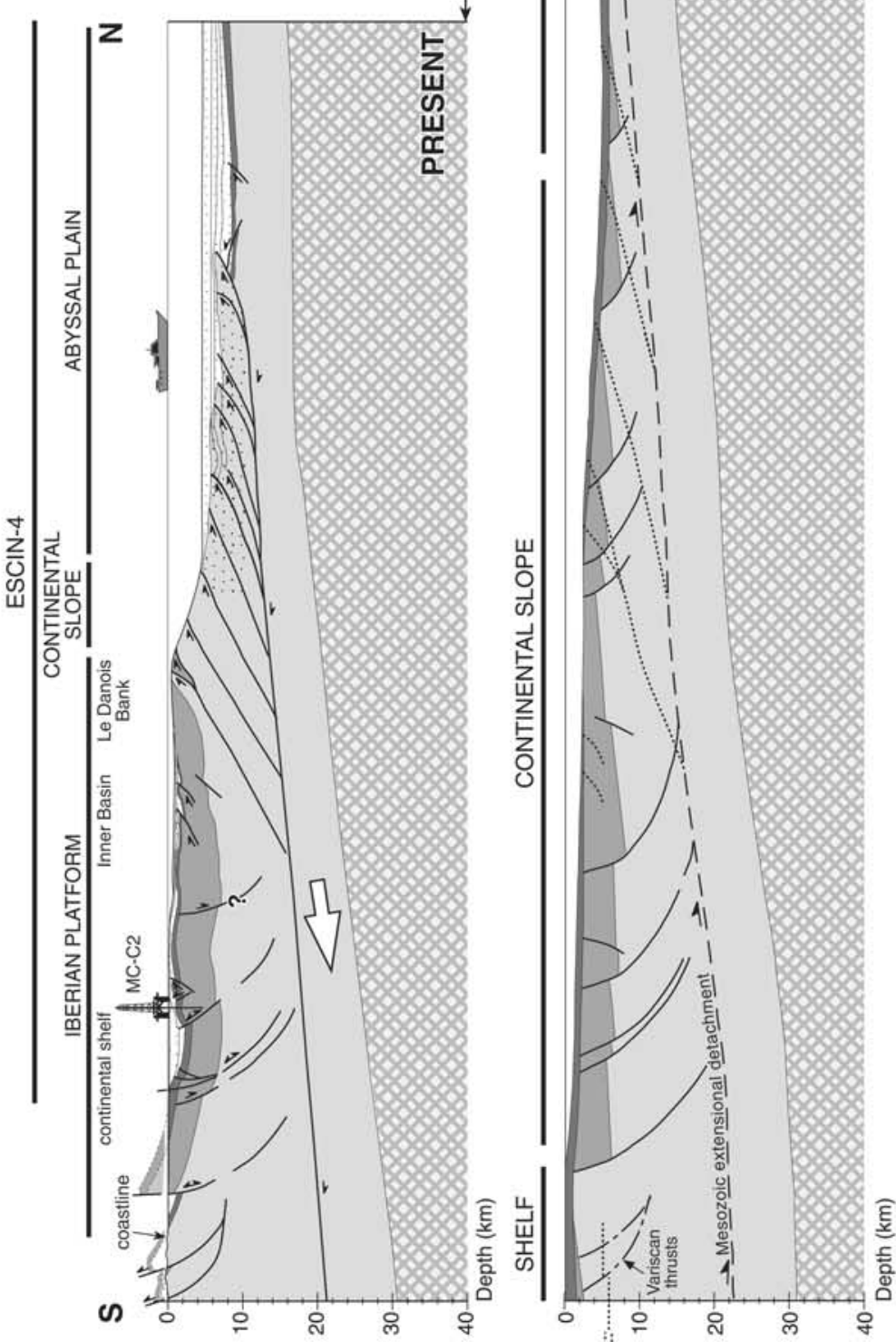

冚

. 홀

을

ठ․

递荡

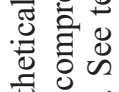

훙.

表交

ฮี $g . n$

:

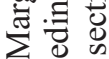

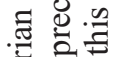

응

号.

范

苯 客

密号恶

氜

空

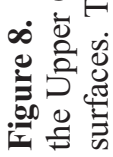


[Gallastegui, 2000]. Previously calculated values for the shortening of the Bay of Biscay based on plate reconstructions range from $120 \mathrm{~km}$ [Grimaud et al., 1982] to $40 \mathrm{~km}$ [Srivastava et al., 1990a]. The shortening calculated for the Pyrenean region by balanced cross-section techniques varies from $75 \mathrm{~km}$ in the west central Pyrenees [Teixell, 1998] to $147 \mathrm{~km}$ in the central Pyrenees [Muñoz, 1992].

[28] The integration of different geophysical and geological results into a single cross section parallel to deep seismic reflection profile ESCIN-4 provides the basis for a new interpretation of the crustal structure of the North Iberian Margin in this sector. Although the Tertiary partial closure of the Bay of Biscay is well established, there is no geological or geophysical evidence of subduction in this area, in the sense of the sinking of oceanic crust in the mantle. In fact, the oceanic nature of the crust of the Bay of Biscay in the studied section is not well established, as the velocity-depth distribution there is poorly constrained. This part of the margin is close to the eastern apex of the Bay of Biscay and the crust would be more likely of very thinned continental type, according to (1) the structural diagram of the Bay of Biscay [Derégnaucourt and Boillot, 1982] (Figure 2), (2) the velocities suggested in the wide-angle model (Figure 7a), and (3) the lack of magnetic anomalies, which vanish toward the east [Sibuet, 1980; Srivastava et al., 1990a] (Figure 2). The nature of the crust and its young age would make it very buoyant and difficult to sink in the mantle [Fernández-Viejo, 1997]. Moreover, all geophysical data presented in this paper suggest that the lower crust is a continuous level under the North Iberian Margin and Bay of Biscay. The negative gravity anomaly in the North Iberian Trough, previously invoked as an evidence of the subduction, is explained in our gravity model as an edge effect related to the northward thinning of the continental crust and to the thick pile of sediments deposited in the North Iberian Trough.
[29] In summary, it is not necessary to assume the presence of a slab of oceanic crust subducting under the North Iberian Margin, to account for the partial closure of the Bay of Biscay in the Tertiary. We propose in our model that the shortening of the upper crustal levels was resolved at the deeper levels by the southward underthrusting of the Cantabrian Margin lower crust along the top of the middle crust. The proposed Mesozoic crustal-scale extensional detachment favored the underthrusting, as it constituted a weakness zone that allowed the lower crust to "slide" southward under the upper crust. The southward underthrusting of the lower crust along a detachment explains the indentation of the Cantabrian Margin crust into the Iberian crust that forced the northward subduction of the Iberian crust under the Cantabrian Mountains. The model is in agreement with previous wide-angle/refraction models of the margin that show a crustal thickening under the Cantabrian Mountains and a duplication of the Moho [Pulgar et al., 1996; Fernández-Viejo, 1997; Gallart et al., 1997; Fernández-Viejo et al., 1998, 2000].

[30] Further research is needed to provide more precise constraints on the crustal structure of the North Iberian Margin, and measurement of seismic velocities with OBS data would be the key element to prove the real nature of the crust (thinned continental or oceanic) and its lateral variations along the margin.

[31] Acknowledgments. This research is part of a Ph.D. funded by the Spanish Education Ministry with a FPI grant. The ESCIN project was sponsored by Spanish CICYT and Asturian FICYT (projects GEO 900660, GEO 91-1086-C02, PB92-1013, AMB98-1012-C02-02, and AMB95-0922). We wish to thank REPSOL for providing the commercial seismic reflection profiles from the Iberian Platform. We thank Montserrat Torné for invaluable help in gravity data processing and analysis. We thank two anonymous reviewers for their helpful comments.

\section{References}

Alonso, J. L., J. A. Pulgar, J. C. García-Ramos, and P. Barba, Tertiary basins and Alpine tectonics in the Cantabrian Mountains (NW Spain), in Tertiary Basins of Spain: The Stratigraphic Record of Crustal Kinematics, edited by P. F. Friend and C. J. Dabrio, pp. 214-227, Cambridge Univ. Press, New York, 1996.

Álvarez-Marrón, J., et al., Seismic structure of the northern continental margin of Spain from ESCIN deep seismic profiles, Tectonophysics, 264, 153174, 1996.

Álvarez-Marrón, J., E. Rubio, and M. Torné, Subduction-related structures in the North Iberian Margin, J. Geophys. Res., 102, 22,497-22,511, 1997.

Ayarza, P., J. R. Martínez Catalán, J. Gallart, J. A. Pulgar, and J. J. Dañobeitia, Estudio Sísmico de la Corteza Ibérica Norte 3.3: A seismic image of the Variscan crust in the hinterland of the NW Iberian Massif, Tectonics, 17, 171-186, 1998.

Boillot, G., and R. Capdevila, The Pyrenees: Subduction and collision?, Earth Planet. Sci. Lett., 121(5), $151-160,1977$.

Boillot, G., and J. Malod, The north and north-west spanish continental margin: A review, Rev. Soc. Geol. Esp., 1(3-4), 295-316, 1988.

Boillot, G., P. A. Dupeuble, M. Lamboy, L. d'Ozouville, and J.-C. Sibuet, Structure et histoire géologique de la marge continentale au $\mathrm{N}$ de l'Espagne, in Histoire Structurale du Golfe de Gascogne, edited by J. Debysier, X. Le Pichon, and M. Montadert, V. 6.1-V.6.52, Technip, París, 1971

Boillot, G., P. A. Dupeuble, and J. Malod, Subduction and tectonics on the continental margin off northern Spain, Mar. Geol., 32, 53-70, 1979.

Boillot, G., M. Montadert, M. Lemoine, and B. BijuDuval (Eds.), Les Marges Continentales Actuelles et Fossiles Autour de la France, Masson, París, 1984.

Córdoba, D., E. Banda, and J. Ansorge, The Hercynian crust in Northwest Spain: A seismic survey, Tectonophysics, 132, 321-333, 1987.

Córdoba, D., E. Banda, and J. Ansorge, $P$-wave velocity-depth distribution in the Hercynian crust of Northwest Spain, Phys. Earth Planet. Int., 51, 235-248, 1988.

Daignières, M., J. Gallart, J. Banda, and A. Hirn, Implications of the seismic structure for the orogenic evolution of the Pyrenees range, Earth Planet Sci. Lett., 57, 88-110, 1982

Dallmeyer, R. D., and E. Martínez-García (Eds.); PreMesozoic Geology of Iberia, Springer-Verlag, New York, 1990.

Derégnaucourt, D., and G. Boillot, Structure Géologique du golfe de Gascogne, Bull. Bur. Rech. Géol. Min., 2, I(3), 149-178, 1982.

Etude Continentale et Océanique par Reflexion et Refraction Sismique (ECORS) Pyrenees Team, The ECORS deep reflection seismic survey across the Pyrenees, Nature, 331, 508-511, 1988.
Fernández-Viejo, G., Estructura cortical de la Cordillera Cantábrica y su transición a la Cuenca del Duero a partir de datos de sísmica de refracción/ reflexión de gran ángulo, Ph.D. thesis, Univ. de Barcelona, Barcelona, Spain, 1997.

Fernández-Viejo, G., J. Gallart, J. A. Pulgar, J. Gallastegui, J. J. Dañobeitia, and D. Córdoba, Crustal transition between continental and oceanic domains along the North Iberian margin from wide-angle seismic and gravity data, Geophys. Res. Lett., 25(23), 4249-4252, 1998.

Fernández-Viejo, G., J. Gallart, J. A. Pulgar, D. Córdoba, and J. J. Dañobeitia, Seismic signature of Variscan and Alpine tectonics in NW Iberia: Crustal structure of the Cantabrian Mountains and Duero Basin, J. Geophys. Res., 105, 3001-3018, 2000.

Gallart, J., E. Banda, and M. Daignières, Crustal structure of the Palaeozoic Axial Zone of the Pyrenees and transition to the North Pyrenean Zone, Ann. Geophys., 37(3), 457-480, 1981.

Gallart, J., G. Fernández-Viejo, J. Díaz, N. Vidal, and J. A. Pulgar, Deep structure of the transition between the Cantabrian Mountains and the North Iberian Margin from wide-angle ESCIN-N data, Rev. Soc. Geol. Esp., 8(4), 365-382, 1997.

Gallastegui, J., Estructura cortical de la cordillera y margen continental cantábricos: Perfiles ESCI-N, Trab. Geol., 21, Univ. de Oviedo, Spain, 231 pp., 2000 . 
Gallastegui, J., J. A. Pulgar, and J. Álvarez-Marrón, 2-D seismic modeling of the Variscan foreland thrust and fold belt in NW Spain from ESCIN-1 deep seismic reflection data, Tectonophysics, 269, $21-$ 32, 1997.

Grimaud, S., B. Boillot, B. J. Collette, A. Mauffret, P. R. Miles, and D. B. Roberts, Western extension of the Iberian-European plate boundary during the Early Cenozoic (Pyrenean) convergence: A new model, Mar: Geol., 45, 63-77, 1982.

Herraiz, M., et al., The recent (upper Miocene to Quaternary) and present tectonic stress distribution in the Iberian Peninsula, Tectonics, 19, 762-786, 2000 .

Julivert, M., Decollement tectonics in the Hercynian Cordillera of NW Spain, Am. J. Sci., 270(1), $1-$ 29, 1971.

Lalaut, P., J. C. Sibuet, and C. Williams, Presentation d'une carte gravimétrique de l'Atlantique nord-est, C. R. Acad. Sci. París, Ser. D, 292, 597-600, 1981.

Lanaja, J. M., Contribución de la exploración petrolífera al conocimiento de la geología de España, 465, Inst. Geol. y Min. de Esp. (IGME), Madrid, 1987.

Le Pichon, X., and F. Barbier, Passive margin formation by low-angle faulting within the upper crust: The Northern Bay of Biscay Margin, Tectonics, 6, 133 $150,1987$.

Le Pichon, X., J. C. Bonnin, J. Francheteau, and J. C. Sibuet, Une hypothèse d'évolution tectonique du Golfe de Gascogne, in Histoire Structurale du Golfe de Gascogne, edited by J. Debysier, X. Le Pichon, and M. Montadert, VI.11.1-VI.11.44, Technip, París, 1971.

Ludwig, J. W., J. E. Nafe, and C. L. Drake, Seismic refraction, in The Sea, edited by A. E. Maxwell, pp. 53-84, John Wiley, New York, 1970.

Malod, J. A., and G. Boillot, Campagne Cyadanois, 9-22 juillet 1979, in Résultats des Campagnes à la Mer, $N^{\circ}$ 20, CNEXO, Brest, 1980.

Malod, J. A., G. Boillot, R. Capdevila, P. A. Dupeuble, C. Lepvrier, G. Mascle, C. Muller, and J. Taugordeau-Lantz, Subduction and tectonics on the continental margin off northern Spain: Observations with the submersible Cyanna, in Trench-Fore Arc Ggeology, edited by J. K. Legget, Geol. Soc. Spec. Publ., 10, 309-315, 1982.

Martínez-García, E., El Pérmico de la región Cantábrica, in Carbonífero y Pérmico de España, edited by
E. Martínez-Díaz, pp. 391-402, Inst. Geol. Min. Esp., Madrid, 1982.

Matte, P., Accretionary history and crustal evolution of the Variscan belt in Western Europe, Tectonophysics, 196, 309-337, 1991.

Montadert, L., B. Damotte, J. P. Fail, J. R. Delteil, and P. Valéry, Structure géologique de la plaine abyssale du Golfe de Gascogne, in Histoire Structurale du Golfe de Gascogne, edited by J. Debysier, X. Le Pichon, and M. Montadert, VI.14.1-VI.14.42, Technip, París, 1971.

Muñoz, J. A., Evolution of a continental collision belt: ECORS-Pyrenees crustal balanced cross section, in Thrust Tectonics, edited by K. McClay, pp. $235-$ 246, Chapman and Hall, New York, 1992.

Pérez-Estaún, A., F. Bastida, J. L. Alonso, J. Marquínez, J. Aller, J. Álvarez-Marrón, A. Marcos, and J. A. Pulgar, A thin-skinned tectonics model for an arcuate fold and thrust belt: The Cantabrian Zone (Variscan Ibero-Armorican Arc), Tectonics, 7, $517-$ 537, 1988.

Pérez-Estaún, A., J. A. Pulgar, E. Banda, and J. Álvarez-Marrón, Crustal structure of the external Variscides in Northwest Spain from deep seismic reflection profiling, Tectonophysics, 232, 91-118, 1994.

Pulgar, J. A., J. Gallart, G. Fernández-Viejo, A. PérezEstaún, J. Álvarez-Marrón, and ESCIN Group, Seismic image of the Cantabrian Mountains in the western extension of the Pyrenees from integrated ESCIN reflection and refraction data, Tectonophysics, 264, 1-19, 1996.

Pulgar, J. A., J. L. Alonso, R. G. Espina, and J. A Marín, La deformación alpina en el basamento varisco de la Zona Cantábrica, Trab. Geol., 21, $283-$ 294, 1999

Roure, F., et al., ECORS deep seismic data and balanced cross sections: Geometric constraints to trace the evolution of the Pyrenees, Tectonics, 8, 41-50, 1989.

Sandwell, D. T., and W. H. F. Smith, Marine gravity anomalies from GEOSAT and ERS-I altimetry, $J$. Geophys. Res., 102, 10,039-10,054, 1997.

Seguret, M., and M. Daignières, Crustal scale balanced cross sections of the Pyrenees, discussion, Tectonophysics, 129, 303-318, 1986.

Sibuet, J. C., and X. Le Pichon, Structure gravimétrique du Golfe de Gascogne et le fossé marginal nordespagnol, in Histoire Structurale du Golfe de Gas- cogne, edited by J. Debysier, X. Le Pichon, and M. Montadert, VI.9.1-VI.9.18, Technip, París, 1971.

Sibuet, J. C., G. Pautot, and X. Le Pichon, Interprétation structurale du Golfe de Gascogne à partir des profils de sismique, in Histoire Structurale du Golfe de Gascogne, edited by J. Debysier, X. Le Pichon, and M. Montadert, VI.10.1-VI.10.32, Technip, París, 1971

Sibuet, J. C., et al., Deep drilling results of Leg 47b (Galicia Bank area) in the framework of the early evolution of the North Atlantic Ocean, Philos. Trans. R. Soc. London, Ser. A, 294, 51-61, 1980.

Srivastava, S. P., W. R. Roest, L. C. Kovacs, G. Oakey, S. Levesque, J. Verhoef, and R. Macnab, Motion of Iberia since the Late Jurassic: Results from detailed aeromagnetic measurements in the Newfoundland Basin, Tectonophysics, 184, 229-260, 1990a.

Srivastava, S. P., H. Schouten, W. R. Roest, K. D. Klitgord, L. C. Kovacs, J. Verhoef, and R. Macnab, Iberian plate kinematics: A jumping plate boundary between Eurasia and Africa, Nature, 344, 756-759, $1990 \mathrm{~b}$.

Teixell, A., Crustal structure and orogenic material budget in the west central Pyrenees, Tectonics, 1-17, $395-406,1998$

Vegas, R., and E. Banda, Tectonic framework and Alpine evolution of the Iberian Peninsula, Earth Evol. Sci., 4, 320-342, 1982.

Verhoeff, J., and S. P. Srivastava, Correlation of sedimentary basins across the North Atlantic as obtained from gravity and magnetic data, and its relation to the early evolution of the North Atlantic, in Extensional Tectonics and Stratigraphy of the North Atlantic Margins, edited by A. J. Tankard and H. R. Balkwill, AAPG Mem., 46, 131-147, 1989 .

Williams, G. D., and M. W. Fischer, A balanced section across the Pyrenean orogenic belt, Tectonics, 3 , $773-780,1984$

J. Gallart, Instituto de Ciencias de la Tierra, Jaume Almera, CSIC, c/ Lluis Sole i Sabaris s/n, 08028 Barcelona, Spain. (jgallart@ija.csic.es)

J. Gallastegui and J. A. Pulgar, Departamento de Geología, Universidad de Oviedo, c/ Jesús Arias de Velasco s/n, 33005 Oviedo, Spain. ( jorge@asturias.geol. uniovi.es; pulgar@asturias.geol.uniovi.es) 